\title{
KARAKTERISTIK KUALITAS AIR DAN KEBERADAAN BAKTERI Vibrio $s p$. PADA WILAYAH TAMBAK UDANG TRADISIONAL DI PESISIR WUNDULAKO DAN POMALAA KOLAKA
}

\author{
Arman Pariakan ${ }^{\mathrm{a}, *}$, Rahim ${ }^{\mathrm{a}}$ \\ a Program Studi Ilmu Perikanan, Fakultas Pertanian, Perikanan dan Peternakan \\ Universitas Sembilanbelas November Kolaka, Kolaka, Indonesia \\ *Koresponden penulis : armanpariakan@gmail.com
}

\begin{abstract}
Abstrak
Penurunan produksi tambak udang vaname telah merugikan para pembudidaya di Kecamatan Wundulako dan Pomalaa, serangan bakteri Vibrio sp. menjadi penyebab utama kejadian tersebut. Keberadaan bakteri Vibrio $s p$. sangat dipengaruhi oleh karakteristik salinitas, amonia dan suhu air. Tujuan dari penelitian ini adalah menganalisis hubungan antara kualitas air (salinitas, suhu, dan amonia) dengan keberadaan bakteri Vibrio sp. Penelitian ini menggunakan 40 data bakteri Vibrio sp. dan data air yang diambil di wilayah tambak udang vaname pada bulan Juni dan Juli, untuk melihat hubungan antar parameter tersebut digunakan analisis statistik non-parametrik generalized additive model, sedangkan untuk melihat sebaran Vibrio sp. menggunakan analisis spasial metode inverse distance weighted. Hasil dari analisis diperoleh nilai hubungan antara kualitas air dengan keberadaan bakteri yang berbeda, yaitu; salinitas 0,0302; suhu air 0,2602; dan 0,4759 untuk amonia. Salinitas antara 20 - >30 ppt mempengaruhi keberadaan bakteri dan semakin kuat pada salinitas >28 ppt, sedangkan suhu air berpengaruh terhadap keberadaan bakteri pada semua tingkatan. Konsentrasi amonia antara 1 - 1,5 mg/l mempengaruhi keberadaan bakteri. Konsentrasi amonia lebih rendah pada salinitas yang tinggi dan sebaliknya. Sedangkan suhu air tidak menunjukkan pola pengaruh terhadap salinitas dan amonia air. Sebaran kondisi lingkungan perairan terhadap keberadaan bakteri Vibrio sp., menunjukkan variasi yang berbeda di setiap lokasi pada bulan Juni dan Juli. Untuk menjaga salinitas tambak, penting untuk memperhatikan input air tawar dalam budidaya udang. Tingginya kandungan amonia di area tambak tradisional dapat mempengaruhi pertumbuhan dan kelangsungan hidup udang vaname yang dipelihara, oleh karena itu penting untuk menggunakan sistem resirkulasi pada budidaya udang vaname ditambah penggunaan bakteri nitrifikasi.
\end{abstract}

Kata kunci: Bakteri Vibrio sp, Generalized additive models, kualitas Air

Abstract

The decrease in the production of vannamei shrimp ponds is detrimental to farmers in Wundulako and Pomalaa sub-districts. Attack Vibrio sp. bacteria has been the main cause of this incident. The presence of bacteria Vibrio $s p$ is strongly influenced by the characteristics of salinity, ammonia, and water temperature. This study aimed to analyze the relationship between water quality (salinity, temperature, and ammonia) with Vibrio sp. This study used 40 data on Vibrio sp. and water data taken in the vannamei shrimp pond area in June and July, to see the relationship between these parameters, non-parametric statistical analysis was used of generalized additive model, while to see the distribution of Vibrio sp. using the inverse distance weighted spatial analysis method. The analysis results obtained the value of the relationship between water quality and the presence of different bacteria, namely; salinity 0.0302 ; water temperature 0.2602 ; and 0.4759 ammonia. Salinity between 20 - >30 ppt affects the presence of bacteria, and is stronger at salinity $>28$ ppt. Whereas, water temperature affects the presence of bacteria at all levels. Ammonia concentration between 1 $-1.5 \mathrm{mg} / \mathrm{l}$ affects the presence of bacteria. It was found that the ammonia concentration was lower at high salinity and vice versa. Meanwhile, the water temperature did not show a pattern of influence on the salinity and ammonia of the water. Distribution of aquatic environmental conditions on the presence of Vibrio sp., showing variation at each location in June and July with the presence of Vibrio sp. To maintain pond salinity, it is essential to pay attention to freshwater inputs in shrimp farming. The high content of ammonia in traditional pond areas can affect the growth and survival of vannamei shrimp that are reared; Therefore, it is essential to use a recirculation system in vannamei shrimp culture the use of nitrifying bacteria.

Keywords: Vibrio sp. bacteria, generalized additive models, water quality 


\section{PENDAHULUAN}

Udang vaname (Litopenaeus vannamei) merupakan satu dari komoditas utama perikanan air payau yang bernilai ekonomis tinggi di Sulawesi Tenggara. Aktivitas pemeliharaan udang vaname (L. vannamei) di tambak dengan metode tradisional dan ketersediaan sumber air payau telah mempermudah masyarakat pesisir untuk melakukan usaha pembudidayaan udang. Namun, dalam proses kegiatan budidaya masih ditemukan kendala yaitu jumlah kematian udang yang tinggi sehingga hasil produksi mengalami penurunan hingga gagal panen. Salah satu daerah yang mengalami penurunan produksi udang vaname (L. vannamei) berada di pesisir Kecamatan Wundulako dan Kecamatan Pomalaa Kabupaten Kolaka.

Para pembudidaya menemukan udang yang mati memiliki ciri tubuh berwarna merah, bercak hitam, dan keropos. Hal ini merupakan tanda dari terjangkitnya udang oleh bakteri Vibrio sp. [1], [2] menyatakan bahwa salah satu spesies bakteri yang paling banyak menyebabkan kematian pada budidaya udang vaname adalah Vibrio sp. Bakteri Vibrio sp. merupakan patogen serius untuk berbagai jenis organisme akuakultur di seluruh dunia [3]. [4] mengemukakan bahwa bakteri Vibrio sp. yang banyak merusak kegiatan budidaya udang berasal dari lingkungan laut hingga muara sungai, [5] menjelaskan bahwa ekosistem laut memiliki resiko penyakit (potensi patogen) lebih tinggi daripada daerah terrestrial.

Kelangsungan hidup udang vaname $(L$. vannamei) di tambak pada wilayah pesisir sangat dipengaruhi oleh kondisi eksternal yaitu faktor biotik (bakteri patogen) dan abiotik (stres lingkungan) [6]. Perubahan lingkungan yang ekstrim dapat mempengaruhi sifat bakteri yang sebelumnya tidak berbahaya menjadi patogenik [7] dan terjadi perubahan pada tingkat virulensi, reproduksi hingga penyebarannya [8], sehingga dapat memperparah kondisi produksi tambak udang. Stres fisiologis yang dialami udang akibat perubahan lingkungan telah banyak diteliti, sedangkan hubungan antara perubahan lingkungan dan keberadaan bakteri patogen pada kawasan budidaya udang vaname ( $L$. vannamei) masih jarang dievaluasi. Kasus perikanan udang di Kabupaten Kolaka pun belum pernah di evaluasi. Berdasarkan hal ini, maka sangat perlu untuk diamati kondisi faktor abiotik seperti salinitas, suhu, dan amonia dalam kaitannya dengan keberadaan bakteri Vibrio sp. Tujuan penelitian ini adalah menganalisis hubungan kualitas air (salinitas, suhu, dan amonia) dengan bakteri Vibrio $s p$.

\section{METODE}

\section{Lokasi dan Waktu}

Penelitian ini dilakukan pada bulan Juni dan Juli 2021 di wilayah tambak udang Kecamatan Wundulako dan Kecamatan Pomalaa, Kabupaten Kolaka Provinsi Sulawesi Tenggara. Pengamatan dan pengambilan sampel dilakukan pada aliran sungai, air pantai (payau), saluran irigasi tambak dan air dalam tambak (Gambar 1). Sampling pada bulan Juni sebanyak 18 lokasi dan bulan Juli sebanyak 22 lokasi. Batas penelitian terletak antara 4 04'56" sampai 4'10'23" lintang selatan dan antara $121^{\circ} 36^{\prime} 37^{\prime \prime}$ sampai $121^{\circ} 36^{\prime} 51^{\prime \prime}$ bujur timur.

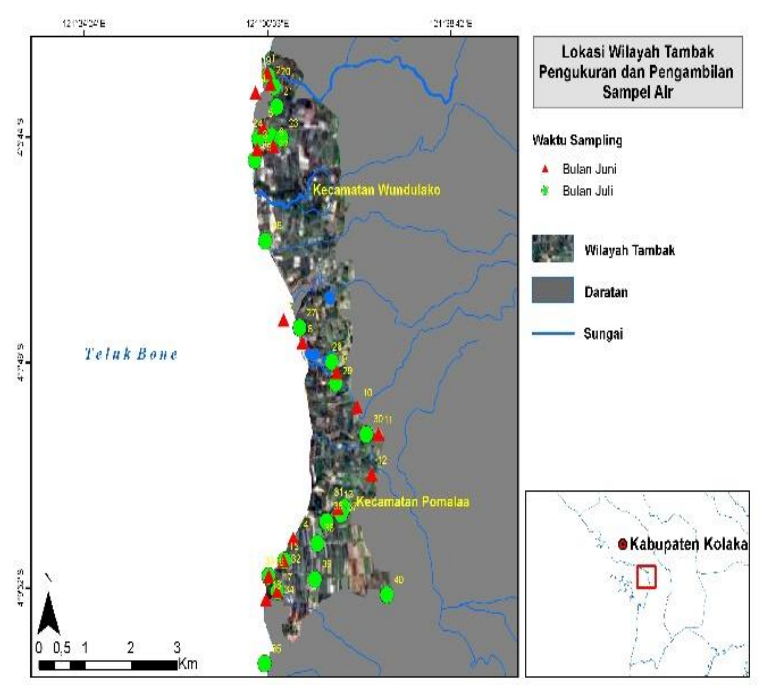

Gambar 1. Lokasi penelitian 


\section{Pengumpulan Data Penelitian}

Variabel dalam penelitian ini disusun berdasarkan studi kepustakaan dan survei yang dijabarkan pada dua pendekatan yaitu pendekatan eksploratif dan deskriptif. Pendekatan eksploratif digunakan untuk menilai kualitas air yakni total bakteri Vibrio sp. (Metode Total Plate Count), amonia (mg/l) (Metode Phenat), salinitas (ppt) (handrefraktometer), suhu $\left({ }^{\circ} \mathrm{C}\right.$ ) (thermometer digital). Pendekatan deskriptif digunakan untuk menelaah pola hubungan kualitas air dengan sebaran bakteri Vibrio $s p$.

\section{Analisis Data}

Hasil dari penelaahan dan penelusuran, kemudian dikumpulkan dan dilanjutkan dengan analisis deskriptif kualitatif menggunakan software microsoft excel 2013, setelah data tersedia dilakukan uji normalitas data dengan metode Shapiro-Wilk, distribusi normal data adalah kondisi ideal namun data bakteri Vibrio sp. (CFU) diambil dari alam dan biasanya data tidak memenuhi asumsi. Bila data tidak normal, maka dilanjutkan dengan analisis statistik non parametrik generalized additive models paket (GAM-MGCV) menggunakan software R 4.0.2. Model GAM dapat mengevaluasi kelimpahan atau biomassa berdasarkan faktor abiotik [9]. Adapun rumus model GAM [10] sebagai berikut:

$$
\begin{gathered}
g\left(\mu_{i}\right)=X_{0}+f_{1}\left(x_{1 i}\right)+f_{2}\left(x_{2 i}\right)+f_{3}\left(x_{3 i}\right) \\
+\cdots+f_{n}\left(X_{n i}\right)
\end{gathered}
$$

Dimana: $g$ : faktor abiotik dan total bakteri Vibrio sp. di air lokasi budidaya, $\mu_{i}$ : Nilai bebas dari variabel terikat, $x_{o}$ : Konstanta model, $f_{n}$ : Fungsi smoothing, $x_{n}$ : Hubungan variabel faktor abiotik faktor abiotik dan total bakteri Vibrio $s p$. di air lokasi budidaya.
Tahap selanjutnya adalah analisis spasial untuk memperoleh gambaran sebaran faktor lingkungan air terhadap keberadaan Bakteri Vibrio sp.(CFU), analisis spasial yang digunakan adalah model interpolasi metode IDW (Inverse Distance Weighted dari software Arcgis 10.2. Data yang diproses yaitu nilai amonia (mg/l), salinitas (ppt), dan suhu $\left({ }^{\circ} \mathrm{C}\right)$ di lokasi penelitian. Prinsip interpolasi IDW adalah memberikan bobot yang lebih tinggi ke titik data yang lebih dekat daripada titik yang lebih jauh [11]. Adapun rumus model interpolasi metode IDW [12] sebagai berikut:

$$
\mathrm{Z}_{0}=\frac{\sum_{i=1}^{N} z_{i} \cdot d_{i}^{-n}}{\sum_{i=1}^{N} d_{i}^{-n}}
$$

Dimana : $\quad Z_{0}$ : Nilai estimasi variabel $\mathrm{z}$ di titik I, $z_{i}$ : Nilai sampel di titik I, $d_{i}:$ Jarak titik sampel ke estimasi titik, $N$ : Koefisien yang menentukan berat, $n$ : Jumlah total prediksi untuk masingmasing area yang yang di validasi.

\section{HASIL DAN PEMBAHASAN}

Uji normalitas data dengan metode Shapiro-Wilk dengan jumlah data bakteri 40 sampel diperoleh nilai sebesar $0.000000002267 \quad(\mathrm{P}>0.05) \quad$ hasil ini menunjukkan bahwa data bakteri atau jumlah bakteri di alam dinamis atau tidak memenuhi asumsi normal.

Tabel 1. Hasil analisis paket (GAM-MGCV)

\begin{tabular}{|c|c|}
\hline Variabel & $P$-value \\
\hline Suhu air & 0.2602 \\
\hline Amonia & 0.4759 \\
\hline Salinitas & $0.0302 *$ \\
\hline
\end{tabular}
pengaruh suhu air, amonia dan salinitas terhadap total bakteri Vibrio sp.

Hasil analisis paket GAM-MGCV (Tabel 1) menunjukkan salinitas berpengaruh kuat terhadap keberadaan bakteri Vibrio $s p$ sebesar 0.0302 , sedangkan suhu air dan amonia tidak 
memberikan pengaruh yang kuat terhadap keberadaan bakteri Vibrio sp.
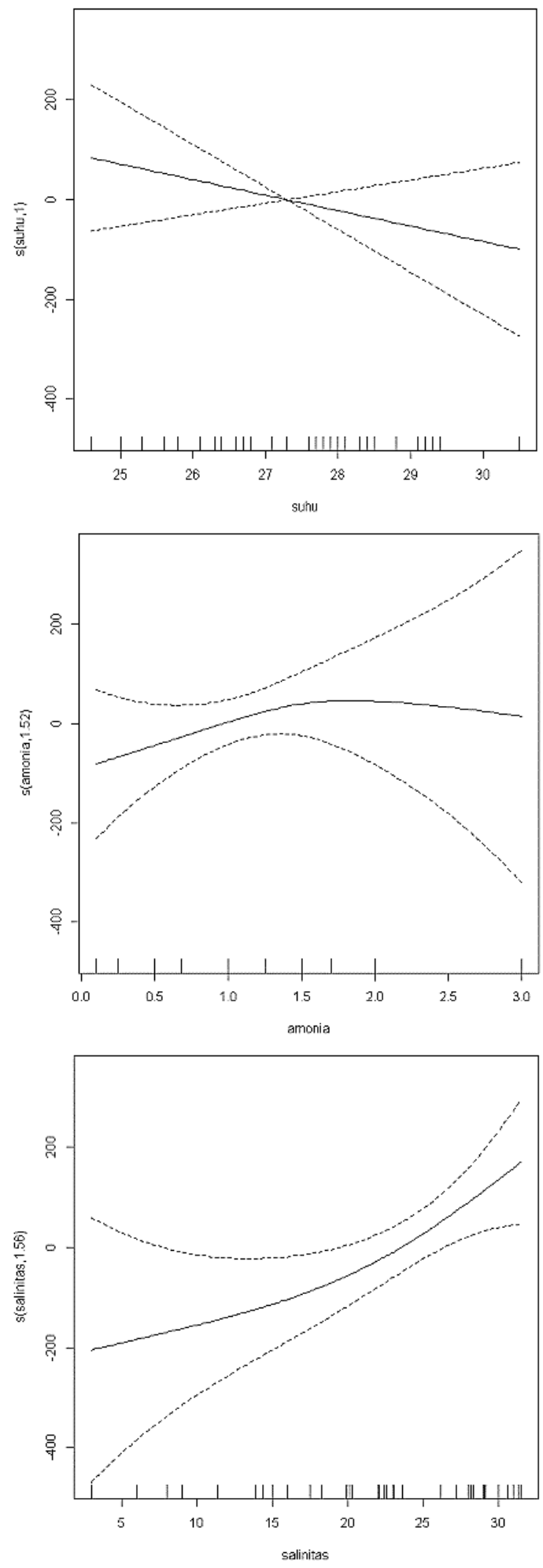

Gambar 2. Grafik analisis paket GAM-MGCV untuk suhu air, amonia dan salinitas terhadap total bakteri vibrio. Kepadatan relatif dari distribusi data ditampilkan di plot sumbu $\mathrm{x}$.

Grafik analisis GAM-MGCV (Gambar 2) kondisi lingkungan air terhadap keberadaan bakteri Vibrio $s p$. memperlihatkan salinitas antara $20->30$ ppt berpengaruh pada keberadaan bakteri dan semakin kuat pada salinitas >28 ppt, sedangkan suhu air memiliki pengaruh terhadap keberadaan bakteri pada semua level. Konsentrasi amonia antara $1-1.5$ $\mathrm{mg} / \mathrm{l}$ berpengaruh terhadap keberadaan bakteri.

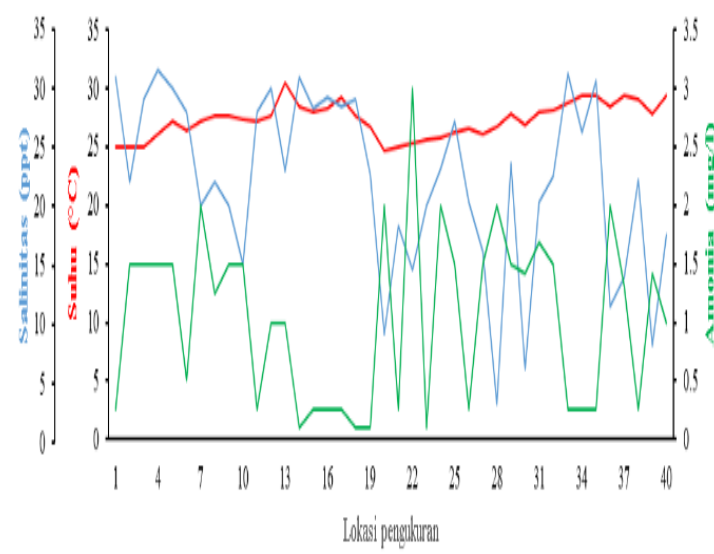

Gambar 3. Kondisi lingkungan air bulan Juni dan Juli : suhu $\left({ }^{\circ} \mathrm{C}\right)$, amonia $(\mathrm{mg} / \mathrm{l})$, dan salinitas (ppt) di wilayah tambak Kecamatan Wundulako dan Kecamatan Pomalaa.

Kondisi Lingkungan air (Gambar 3) suhu, amonia dan salinitas selama penelitian menunjukkan pola yang dinamis, dimana pada kondisi salinitas yang semakin tinggi, konsentrasi amonia semakin rendah dan sebaliknya. Olehnya, salinitas air laut perlu dijaga pada salinitas $19 \mathrm{ppt}$, sedangkan suhu air tidak menunjukkan pola pengaruh terhadap salinitas dan amonia air.

Sebaran kondisi lingkungan air (Gambar 4) terhadap keberadaan bakteri Vibrio sp., menunjukkan bahwa suhu perairan di wilayah tambak udang tersebar tidak merata di setiap bulan juni dan juli dengan nilai antara 24,6 
hingga $30,5^{\circ} \mathrm{C}$, suhu perairan cenderung lebih hangat di daerah kecamatan Pomalaa. Hal ini mungkin disebabkan pengukuran yang dilakukan pada bulan Juni sudah mencapai tengah hari, namun pengukuran pada bulan Juli dilakukan saat cuaca berawan gelap. Total bakteri yang tersebar pada bulan Juni antara 10 - 1510 CFU lebih tinggi dibandingkan pada bulan Juli antara 0 - 370 CFU.
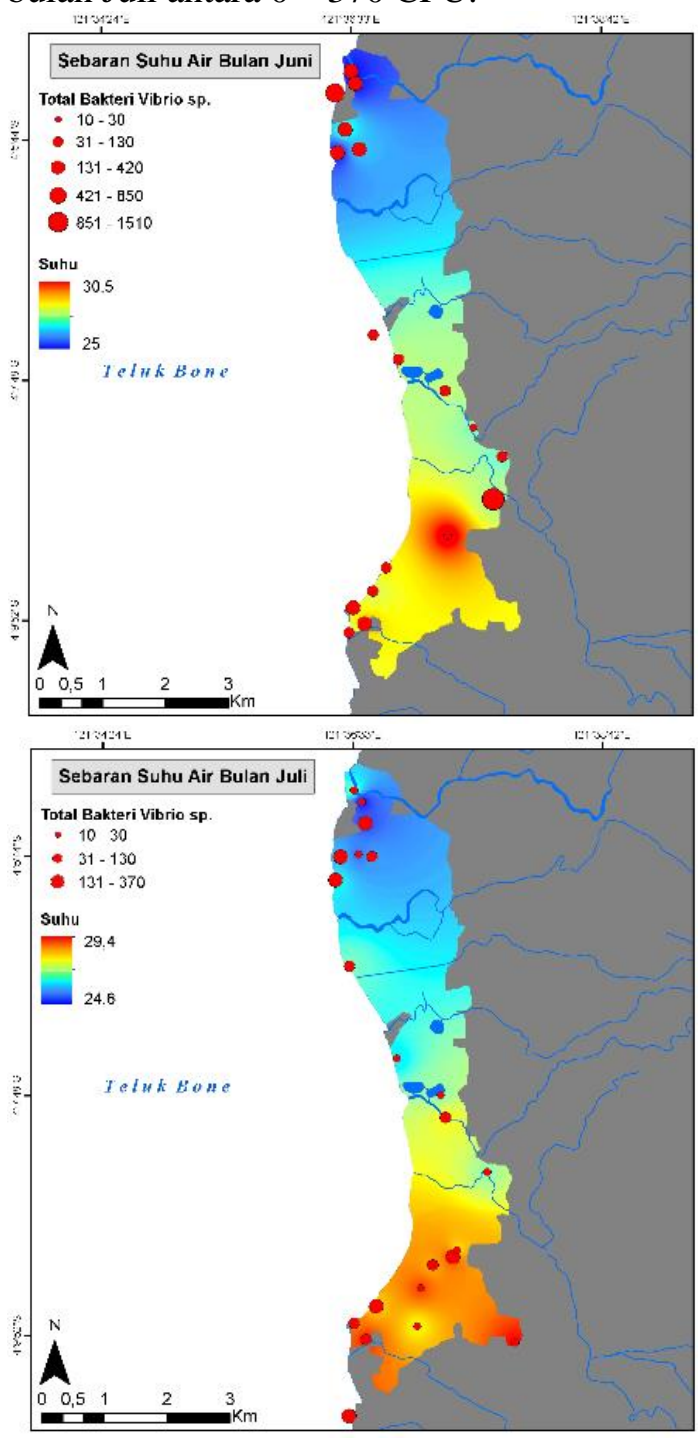

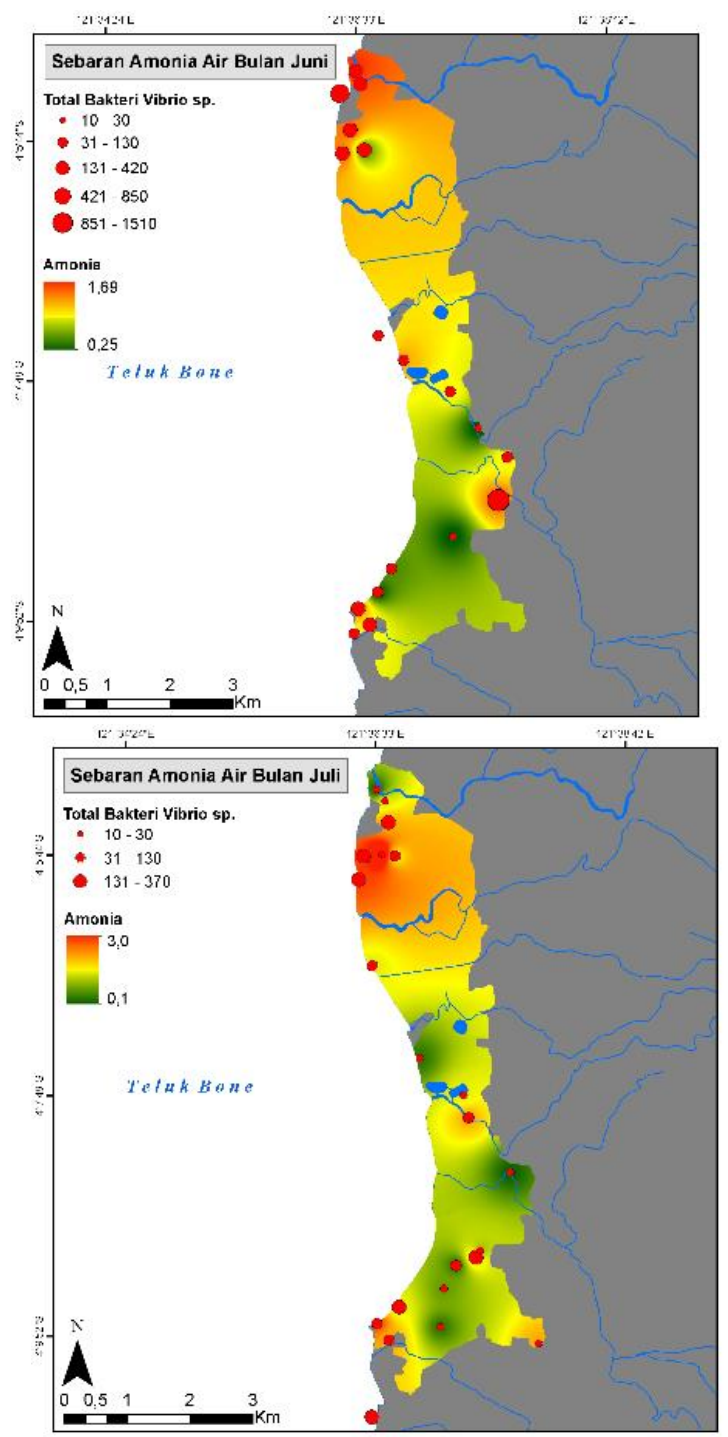




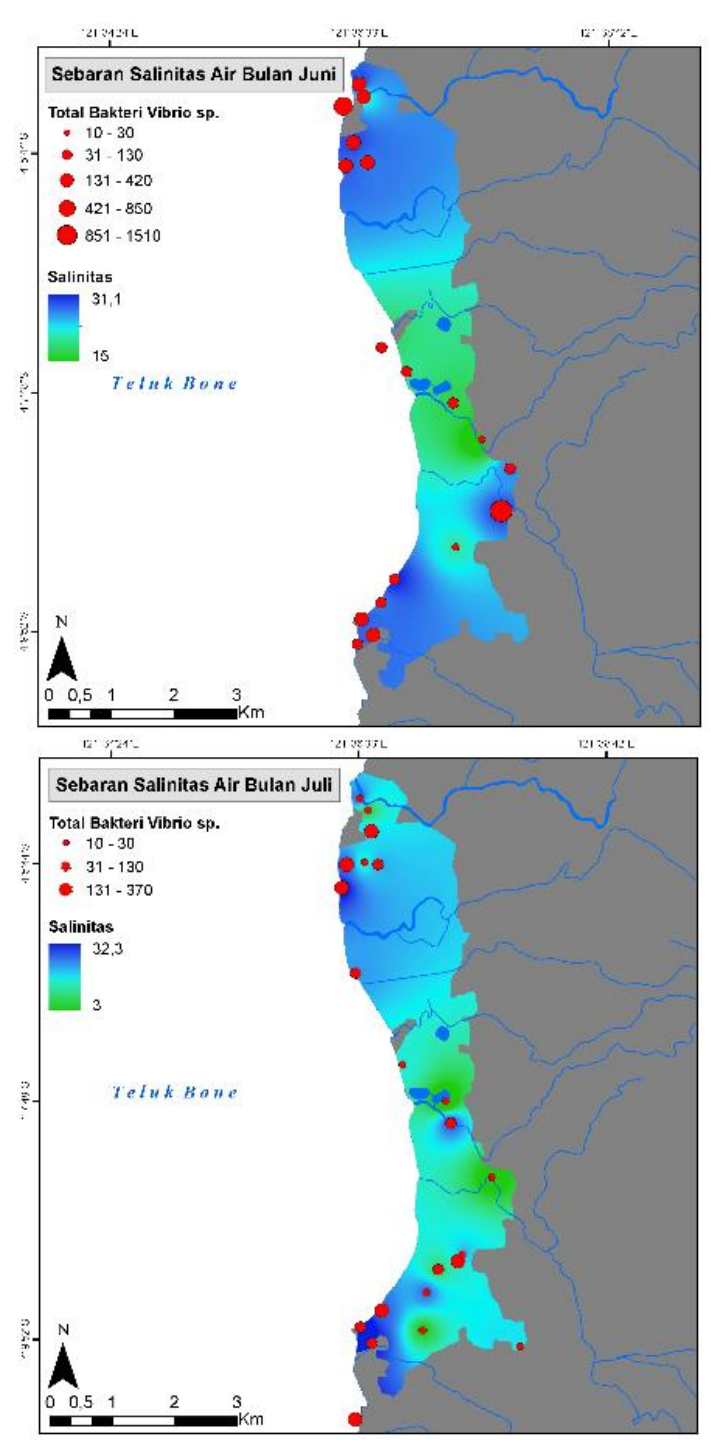

Gambar 4. Kondisi lingkungan air bulan Juni dan Juli : suhu $\left({ }^{\circ} \mathrm{C}\right)$, amonia (mg/l), dan salinitas (ppt) terhadap sebaran bakteri Vibrio sp. di wilayah tambak Kecamatan Wundulako dan Kecamatan Pomalaa

Konsentrasi amonia cenderung lebih tinggi di kecamatan Wundulako, tingginya jumlah bakteri tidak diikuti dengan tingginya konsentrasi amonia pada bulan Juni antara 0,25 - 1,69 mg/l maupun bulan Juli antara 0,1 - 3 $\mathrm{mg} / \mathrm{l}$. Sedangkan sebaran salinitas di wilayah tambak berfluktuasi pada bulan Juni dan Juli. Sebaran salinitas lebih tinggi dan lebih banyak ditemui pada bulan Juni antara 15 - 31,1 ppt dibandingkan bulan Juli antara 3 - 32,3 ppt, salinitas yang rendah pada bulan juli dikarenakan intensitas curah hujan pada bulan Juli lebih tinggi dibandingkan dengan bulan Juni. Total bakteri ditemukan semakin tinggi pada salinitas yang tinggi.
Selama pengukuran dan pengambilan sampel air di wilayah tambak tidak ditemukan udang yang terjangkit bakteri Vibrio $s p$. Ditemukan total bakteri vibrio sp (CFU) tinggi pada tambak udang dan air pantai, kemudian diikuti pada saluran irigasi tambak dan sangat rendah pada aliran sungai.

Kondisi kualitas air suhu, salinitas dan amonia secara berturut-turut mempengaruhi keberadaan bakteri vibrio $s p$. di wilayah tambak udang Kecamatan Wundulako dan Kecamatan Pomalaa dengan konsentrasi salinitas air yang cenderung semakin tinggi diikuti dengan meningkatnya jumlah bakteri di air, namun konsentrasi amonia cenderung tidak 
berpengaruh pada keberadaan bakteri Vibrio $s p$., hal yang sama ditemukan oleh [13] dimana salinitas yang tinggi dan terdapatnya konsentrasi amonia memperlihatkan bahwa pertumbuhan Vibrio sp. meningkat di tambak udang, [14] menjelaskan bahwa salinitas air (tinggi atau rendah) berkorelasi signifikan dengan keberadaan bakteri. [4] menjelaskan bahwa bakteri Vibrio sp. merupakan mikroflora alami dari air laut (bakteri gram negatif) yang bersifat patogen oportunistik. Infeksi oleh bakteri Vibrio $s p$. pada udang dapat terjadi pada stadia nauplius, zoea, mysis dan post larva sampai pada udang dewasa di tambak pembesaran, bersifat akut dan ganas [15] atrofi yang parah pada sel epitel [16]. [17] menjelaskan bahwa udang yang terinfeksi bakteri Vibrio sp. menunjukkan gejala berupa nafsu makan berkurang, berenang miring, bergerak mendekati gelembung udara, kemerahan pada kaki renang dan uropod serta terjadi nekrosis dan melanisasi pada segmen tubuh. Konsentrasi amonia ditemukan semakin tinggi pada salinitas yang rendah dan sebaliknya, [18] menemukan bahwa salinitas air yang rendah dapat meningkatkan konsentrasi amonia, nitrit dan nitrat. [19] menjelaskan bahwa peningkatan konsentrasi amonia dapat membuat organisme akuatik rentan terhadap stres hingga mengalami kematian. Paparan konsentrasi amonia dapat meningkatkan apoptosis hemosit yang mempengaruhi imunitas udang vaname [20]. Tidak berdampak kuatnya konsentrasi amonia terhadap keberadaan bakteri dalam penelitian ini, namun konsentrasi amonia sangat berpengaruh pada kesehatan, pertumbuhan, dan kelangsungan hidup udang vaname yang dibudidayakan. Kondisi tubuh udang vaname yang stres dapat dengan mudah terjangkit bakteri patogen. Asal keberadaan amonia yang tinggi dilokasi penelitian juga dikarenakan sisa dari pakan yang tidak di konsumsi udang peliharaan dan penggunaan pupuk kandang yang diharapkan untuk memberi nutrisi penumbuhan plankton.

Berdasarkan kondisi lingkungan air saat penelitian dengan salinitas $>20$ ppt dapat menyebabkan peningkatan keberadaan bakteri
Vibrio sp. dan salinitas yang rendah dapat meningkatkan konsentrasi amonia, maka disarankan pembudidaya di kecamatan Wundulako dan Kecamatan Pomalaa untuk menjaga nilai salinitas 19 ppt. Hal yang dapat dilakukan pembudidaya untuk mengurangi konsentrasi amonia yaitu budidaya udang vaname berbasis sistem resirkulasi ditambah penggunaan bakteri nitrifikasi untuk mengubah amonia menjadi nitrat. Sangat penting untuk diperhatikan kondisi salinitas dan konsentrasi amonia bagi kelangsungan hidup dan kesehatan udang vaname yang dibudidaya, [21] menjelaskan bahwa salinitas antara 15 - 20 ppt dapat memberikan hasil pertumbuhan vaname yang baik. [22] menjelaskan bahwa konsentrasi amonia 0,45 $\mathrm{mg} / \mathrm{l}$ masih aman bagi budiaya udang vaname sedangkan pada konsentrasi $1,29 \mathrm{mg} / \mathrm{l}$ menyebabkan kematian.

Tambak yang berada di wilayah Kecamatan Wundulako dan Kecamatan Pomalaa, dilakukan dengan teknik tradisional dimana sumber air yang masuk mengikuti gerakan air laut pasang, sehingga kegiatan tambak udang di wilayah ini memang sangat rentan untuk diserang penyakit Vibrio $s p$., hal ini sejalan dengan [23] dimana kegiatan budidaya udang vaname ( $L$. vannamei) secara konvensional merupakan kegiatan yang paling terdampak kerugian dengan pertukaran airnya. Infeksi pada udang diakibatkan adanya hubungan antara host, patogen, dan faktor lingkungan [24].

Hasil analisis GAM pada Gambar 2 menunjukkan bahwa semua level suhu air berpengaruh pada keberadaan bakteri [25] dan [26] menemukan bahwa perubahan suhu air telah terbukti menyebabkan penyakit mudah menular pada udang vaname (L. Vannamei). Wilayah penelitian dengan lintang selatan $4^{\circ}$ dipastikan mendapatkan paparan panas matahari yang lebih panjang terutama pada musim kemarau, dengan kondisi ketinggian air yang dangkal pada tambak udang tradisional dapat meningkatkan suhu air tambak. [27] menemukan bahwa meningkatnya suhu air dapat menyebabkan perubahan dalam sistem pernapasan dan phenol oxidase pada udang 
vaname. Kenaikan suhu juga dapat membuat udang yang dipelihara mengalami hyper thermal, sehingga meningkatkan stres pada udang dan mudah terjangkit bakteri patogen seperti Vibrio $s p$. Jenis Bakteri Vibrio parahaemolyticus dapat tumbuh pada suhu antara 15 dan $30^{\circ} \mathrm{C}$ [28], dan bakteri ini pertumbuhannya turun pada suhu dibawah $15^{\circ} \mathrm{C}[29]$.

Kenaikan suhu air yang tinggi di lokasi penelitian dimulai saat memasuki tengah hari dan semakin panas pada tengah hari, sehingga kondisi suhu air perlu dijaga agar tidak memberikan peluang waktu generasi bakteri. [30] menemukan bahwa bakteri Vibrio parahaemolyticus tumbuh lebih baik pada suhu air 30 dan $37^{\circ} \mathrm{C}$. Untuk menurunkan dan menstabilkan suhu air di kolam tambak udang Kecamatan Wundulako dan Kecamatan Pomalaa dapat menggunakan budidaya sistem resirkulasi yang bertujuan untuk memasukkan air dengan suhu yang lebih dingin ke dalam tambak udang ditambah penggunaan kincir air.

\section{KESIMPULAN}

Salinitas berpengaruh kuat terhadap keberadaan bakteri Vibrio $s p$. di wilayah tambak udang, sedangkan suhu air dan amonia tidak memberikan pengaruh yang kuat terhadap keberadaan bakteri Vibrio $s p$. Olehnya itu penting untuk mengontrol nilai salinitas dengan input air tawar ke dalam tambak budidaya udang. Tingginya jumlah amonia pada wilayah tambak tradisional dapat mempengaruhi pertumbuhan dan kelangsungan hidup udang vaname yang dipelihara, olehnya itu penting untuk menggunakan sistem resirkulasi ditambah penggunaan bakteri nitrifikasi.

\section{UCAPAN TERIMA KASIH}

Ucapan terima kasih disampaikan kepada Direktorat Sumber Daya Direktorat Jenderal Pendidikan Tinggi Kementerian Pendidikan dan Kebudayaan Republik Indonesia yang telah memberikan bantuan biaya penelitian melalui skema Penelitian Dosen Pemula tahun 2021.

\section{DAFTAR PUSTAKA}

1) Food and Agriculture Organization of the United Nations/World Health Organization. "Risk assessment of Vibrio parahaemolyticus in seafood: Interpretative summary and technical report Microbiological Risk Assessment Series". Geneva, Switzerland: World Health Organization and Food and Agriculture Organization of the United Nations., Vol. 16, p. 193, 2011.

2) A.Hatmanti,. "Penyakit Bakterial Pada Budidaya Krustasea Serta Cara Penanganannya". Oseana, 28(3): 1-10, 2003.

3) S. A. Soto-Rodriguez, B. Gomez-Gil, R. Lozano, R. D. Rio-Rodriguez, A. L. Dieguez, J. L. Romalde. "Virulence of Vibrio harveyi responsible for the "brightred" syndrome in the pacific white shrimp Litopenaeus vannamei. J Invert Pathol. 109:307-317, 2012.

4) C. A. M. Cardenas, and M. P. S. Saavedra, "Inhibitory Effect of Benthic Diatom Species on Three Aquaculture Pathogenic Vibrios". Algal Research, 27: 131-139, 2017.

5) G. Reinheimer, "Aquatic Microbiology". 4th edition. Wiley, New York, 1992.

6) C. M. Crain, K. Kroeker, and B. S. Halpern, "Interactive and cumulative effects of multiple human stressors in marine systems". Ecology Letters 11:1304-1315, 2008.

7) K. D. Lafferty, J. W. Porter, and S. E. Ford, "Are diseases increasing in the ocean? Annual Review of Ecology", Evolution and Systematics 35:31-54, 2004. 
8) L. H. T. Vergeer and C. den Hartog,"Omnipresence of Labyrinthulaceae in seagrasses. Aquatic Botany 48:1-20, 1994.

9) J. Irisarri, A. M. Cubillo, M. Jose Fernandez-Reiriz and U. Labarta, "Growth variations within a farm of mussel (Mytilus galloprovincialis) held near fish cages: importance for the implementation of integrated aquaculture". Aquaculture Research, 46 : 1988-2002, 2015.

10) S. N. Wood, Generalized Additive Models "An Introduction with R Second Edition". CRC Press, 2017.

11) Kitsiou D. and M. Karydis, Categorical mapping of marine eutrophication based on ecological indices. Sci. Total Environ., 255:113-127, 2000

12) Burrough, P.A., McDonnell, R.A., Creating continuous surfaces from point data. In: Burrough, P.A., Goodchild, M.F., McDonnell, R.A.,Switzer, P.,Worboys, M. (Eds.), Principles of Geographic Information Systems. Oxford University Press, Oxford, UK. 1998.

13) P. P. M Heenatigala, and M. U. L Fernando, " Occurrence of Bacteria Species Responsible for Vibriosis in Shrimp Pond Culture Systems in Sri Lanka and Assessment of The Suitable Control Measures". Sri lanka Journal Aquatic Science, 21(1): 1-17, 2016.

14) J. Xiong, L. Xuan, W. Yu, J. Zhu, Q. Qiu, J. Chen, "Spatiotemporal successions of shrimp gut microbial colonization: high consistency despite distinct species pool". Environ. Microbiol. 21(4), 1383-1394, 2019.

15) Sarjito, M. Apriliani, D. Afriani, dan A. H. C .Haditomo, "Agensia Penyebab
Vibriosis Pada Udang Vaname (Litopenaus vannamei) Yang Dibudidayakan Secara Intensif Di Kendal". Jurnal Kelautan Tropis, 18(3): 189-196. 2015.

16) B. Krishna-Kumar, V. Kumar-Deekshit, J. Mohan-Raj, P. Praveen-Rai, B. MallappaShivanagowda,., and I. Karunasagar, "Diversity of Vibrio parahaemolyticus associated with disease outbreak among cultured Litopenaeus vannamei (Pacific white shrimp) in India". Aquaculture, 433:247-251, 2014.

17) W. Utami, Sartijo dan Desrina, "Pengaruh salinitas terhadap efek infeksi Vibrio harveyi pada udang vaname (Litopenaeus vannamei)". Jurnal of Aquaculture Management and Technology, 5(1), 8290, 2016.

18) J.H Kim, Y.J Kang, K.I Kim, J.H Kim, 2019. "Toxic effects of nitrogenous compounds (ammonia, nitrite, and nitrate) on acute toxicity and antioxidant responses of juvenile olive flounder", Paralichthys olivaceus. Environ. Toxicol. Pharmacol. 2019.

19) S A. Kathyayani, M. Poornima, S. Sukumaran, A. Nagavel, M. Muralidhar, "Effect of ammonia stress on immune variables of Pacific white shrimp Penaeus vannamei under varying levels of $\mathrm{pH}$ and susceptibility to white spot syndrome virus". Ecotoxicology and Environmental Safety 184, 109626, 2019

20) L. Fei, S. Li, Y.Yu, M. Sun, J. Xiang, F $\mathrm{Li}$, "Effects of ammonia stress on the hemocytes of the Pacific white shrimp Litopenaeus vannamei" Chemosphere 239,124759. 2020.

21) A. Mustafa, "Kriteria Kesesuaian Lahan Untuk Berbagai Komoditas Di Tambak. Media Akuakultur", Vol 7(2) 108-118, 2012. 
22) M. H. Khanjani, M.M. Sajjadi, M. Alizadeh, and Sourinejad, "Study on nursery growth performance of Pacific white shrimp (Litopenaeus vannamei Boone, 1931) under different feeding levels in zero water exchange system". Iranian Journal of Fisheries Sciences 15(4): 1465-1484, 2016.

23) H. Su, X. Hu, Y. Xu, W. Xu, X. Huang, G. Wen, K. Yang, Z. Li, Y. Cao, "Persistence and spatial variation of antibiotic resistance genes and bacterial popu lations change in reared shrimp in South China”. Environ. Int. 119, 327-333, 2018.

24) J. Xiong, J. W. Dai, C. Li, "Advances, challenges, and directions in shrimp disease control: the guidelines from an ecological perspective". Appl. Microbiol. Biotechnol. 100 (16), 6947-6954, 2016.

25) Y. Y. Tang, P. Y. Tao, J. G. Tan, H. Z. Mu, L. Peng, D. D. Yang, S. L. Tong, L. M. Chen, "Identification of Bacterial Community Composition in Freshwater Aquaculture System Farming of Litopenaeus vannamei Reveals Distinct Temperature-Driven Patterns". Int J Mol Sci. 15(8), 13663-13680, 2014.

26) L. F. Aranguren, J. E. Han, and K. F. J. Tang, Enterocytozoon hepatopenaei (EHP) is A Risk Factor for Acute Hepatopancreatic Necrosis Disease (AHPND) and Septic Hepatopancreatic
Necrosis (SHPN) in The Pacific White Shrimp Penaeus vannamei. Aquaculture, 471: 37-42, 2017.

27) K. H. F. Alonzo, R. E. Cadiz, R F. M. Traifalgar, V. L. Corre Jr, "Immune responses and susceptibility to Vibrio parahaemolyticus colonization of juvenile Penaeus vannamei at increased water temperature". AACL Bioflux, 10, (5), $1238-1247,2017$.

28) R. J. Thompson, M. A. Randa, L. A Marcelino, A. T. Mitchell, E. Lim, and M. F. Polz, "Diversity and dynamics of a North Atlantic coastal Vibrio community". Applied and Environmental Microbiology, 70(7), 4103-4110. 2004.

29) Y. Wang, H. Zhang, E. K. Fodjo, C. Kong, G. Run-Run, F. Han, and S. Xiao-Sheng, "Temperature effect study on growth and survival of pathogenic Vibrio parahaemolyticus in Jinjiang oyster (Crassostrea rivularis) with rapid count method". Journal of Food Quality, 6, 2018.

30) S. A. Soto-Rodriguez, R. Lozano-Olvera, D. A. Palacios-Gonzalez, C. Bolan-Mejia, K. G. Rendon-Aguilar, "Characterization and growth conditions of Vibrio parahaemolyticus strains with different virulence degrees that cause acute hepatopancreatic necrosis disease in Litopenaeus vannamei”. J World Aquacult Soc. 1-14, 2019. 